\title{
Penile Intraepithelial Neoplasia: Successful Treatment with Topical 5\% Imiquimod Cream
}

\author{
Slobodan STOJANOVIĆ ${ }^{1 *}$, Nada VUČKOVIĆ ${ }^{2}$, Dragan VEMIĆ 3 \\ ${ }^{1}$ Faculty of Medicine, University of Novi Sad, Clinic of Dermatovenereology Diseases Clinical Center of Vojvodina, Novi \\ Sad, Republic of Serbia \\ ${ }^{2}$ Faculty of Medicine, University of Novi Sad, Center of Pathology and Histology, Clinical Center of Vojvodina, Novi Sad, \\ Republic of Serbia \\ ${ }^{3}$ Clinic of Dermatovenereology Diseases, Clinical Center of Vojvodina, Novi Sad, Republic of Serbia \\ *Correspondence: Slobodan STOJANOVIĆ, e-mail: slobodanstojanovicns@sbb.rs \\ UDC 616.66-006-08:616.454.1 \\ VERSITA
}

\begin{abstract}
The authors present a case of a 36-year-old man with a penile intraepithelial neoplasia who was evaluated at the Outpatient Clinic of the Department of Dermatovenereology Diseases of the Clinical Center of Vojvodina in December of 2010. The patient was referred to this facility by an urologist and had histopathological reports of 4 biopsy specimens taken from different plaques on the glans penis. Biopsy samples were collected from lesions which were clinically diagnosed as leukoplakia. Histopathological findings of all biopsy specimens showed: "dysplasio epithelii planocellularis gradus levioris et partim gradus mediocris diffusa". Given the histopathological diagnosis, the patient was referred to a dermatologist for conservative therapy of these lesions, avoiding radical surgery. On admission, the patient presented with slightly indurated erythematous plaques with some desquamation at the surface, and a tendency for diffuse involvement of the entire glans penis. Topical $5 \%$ imiquimod cream was administered on the lesions once a day and was washed off after 8 hours during 10 weeks. Check-ups were scheduled for every other week in order to assess the course and progress of topical treatment. No significant side effects were recorded, except for acute local inflammation accompanied by mild exudation and itching. After 10 weeks of treatment, complete regression of lesions was achieved, and in the following period of 18 months (until present) no recurrence was observed.
\end{abstract}

\section{Key words}

Penile Neoplasms; Aminoquinolines; Administration, Topical; Treatment Outcome

$\mathrm{T}$ he aim of this report is to present effects of topical $5 \%$ imiquimod cream in the treatment of grade II penile intraepithelial neoplasia.

\section{Introduction}

Epithelial dysplasia is a term used to describe tissue changes including disturbed epithelial cell polarity and maturity, nuclear atypia, increased mitotic activity and nuclear cytoplasmic ratio. Today, these changes on the glans and prepuce of the penis are known as epithelial dysplasia or penile intraepithelial neoplasia (PIN) (1-4). The term PIN indicates clinical entities which used to be regarded as precancerous lesions. All grades of epithelial dysplasia or PIN are histological pre-stages of carcinoma in situ which may gradually lead to penile squamous cell carcinoma (SCS). PIN or penile epithelial dysplasia grading I, II or III, depends on the extent of epithelial involvement by atypical basaloid cells $(1,2)$. Literature review suggests a strong association between human papilloma virus (HPV) and PIN $(1,2,3)$.

\section{Case report}

A 36-year-old man was first evaluated by a dermatologist at the Outpatient Clinic of the Clinical Center of Vojvodina in August 2010. He was referred 
by a urologist and had histological reports of 4 biopsy specimens collected from different plaques on the glans penis. Histological findings of all specimens showed epidermal dysplasia, that was PIN grade II. Apart from mild mucosal "tightness" on the glans, the patient was symptom-free.

Personal history revealed that the patient was circumcised at the age of 15 and without malignant or systemic diseases. Topical 5\% imiquimod cream was not contraindicated.

Family history revealed that none of the patient's immediate or extended family members suffered from mucosal genital or skin diseases. None of his immediate family members suffered from malignant diseases.

Clinical examination showed that on admission, the patient presented with slightly indurated erythematous plaques with some desquamation at the surface and diffuse involvement of the glans penis and sulcus coronarius (Fig. 1, 2). Physical examination of organs and organ systems showed no pathological findings and regular vital signs.
Histopathological findings All biopsy specimens from the glans mucosa showed a stratified squamous epithelium with mild parakeratosis, mild to moderate cell dysplasia, disturbed cell maturity, nuclear atypia with hyperchromatosis, perinuclear halo (discrete koilocytosis) on some cells, basal membranes without changes and of the same thickness, abnormal infiltrate distribution of lymphocytes and plasma cells in mildly edematous lamina propria around slightly dilated blood vessels, and no dyskeratosis. Based on these findings, the following diagnosis was made: dysplasio epithelii planocellularis gradus levioris (I) et partim gradus mediocris (II) mucosae (Fig. 3).

Relevant laboratory tests revealed no abnormal results including serology on syphilis and testing for HIV.

Treatment $A$ thin layer of $5 \%$ imiquimod cream (Aldara cream) was applied once a day and was washed off 8 hours later for 5 days in a week during 10 weeks. Check-ups were scheduled for every other week by a dermatology specialist who established local inflammation accompanied by mild exudation

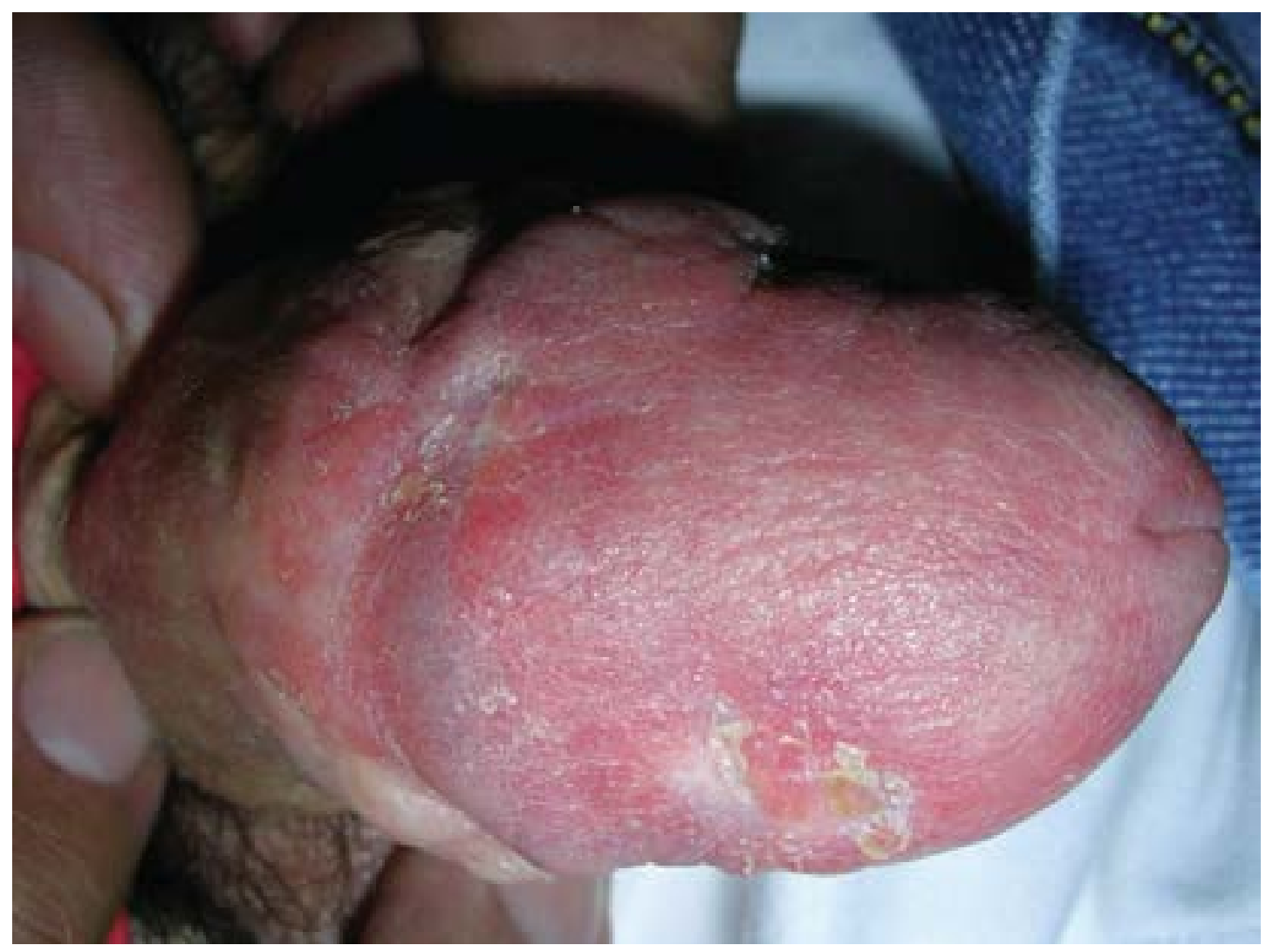

Figure 1. Clinical findings before topical treatment 


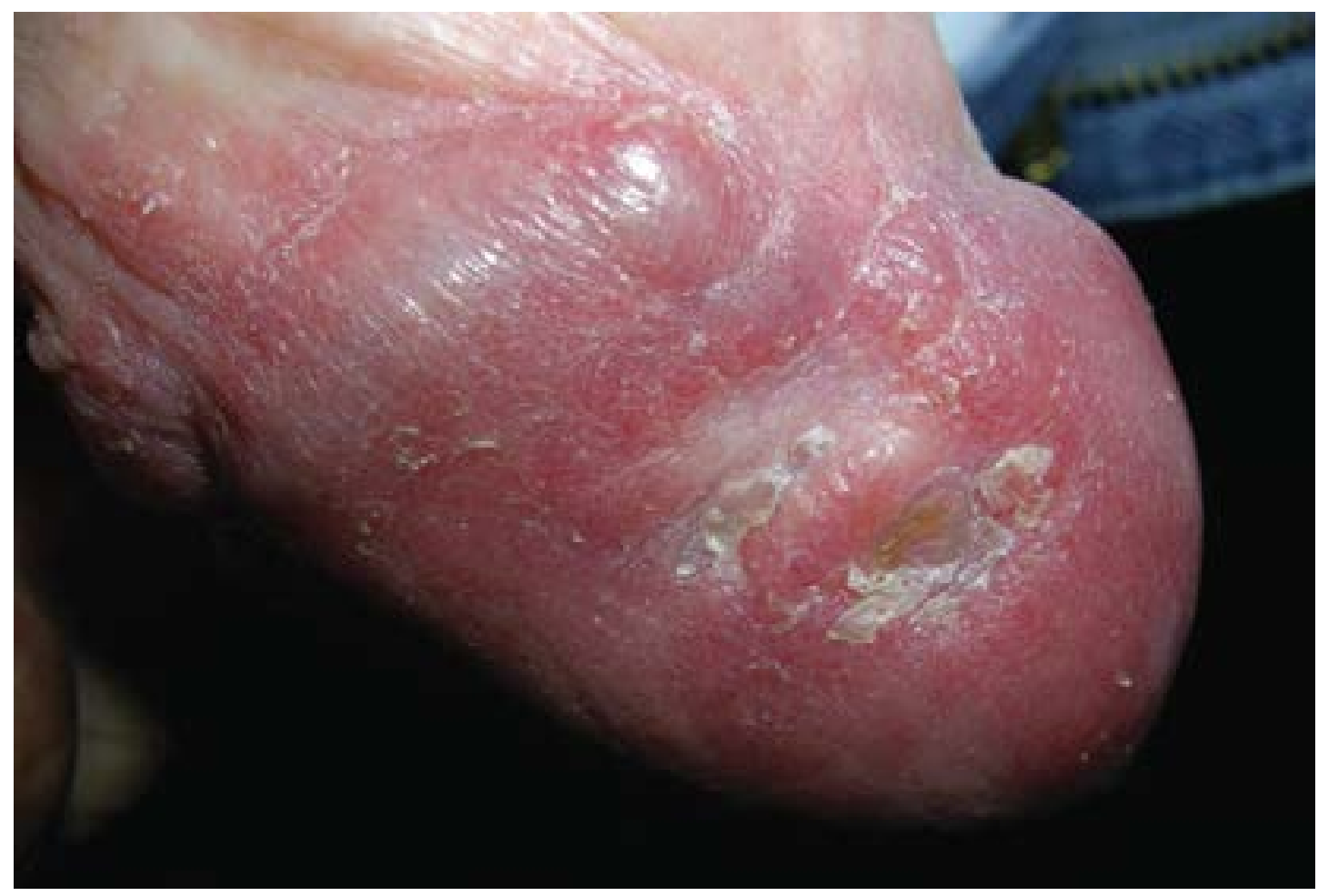

Figure 2. Clinical findings before topical treatment with the visible biopsy site

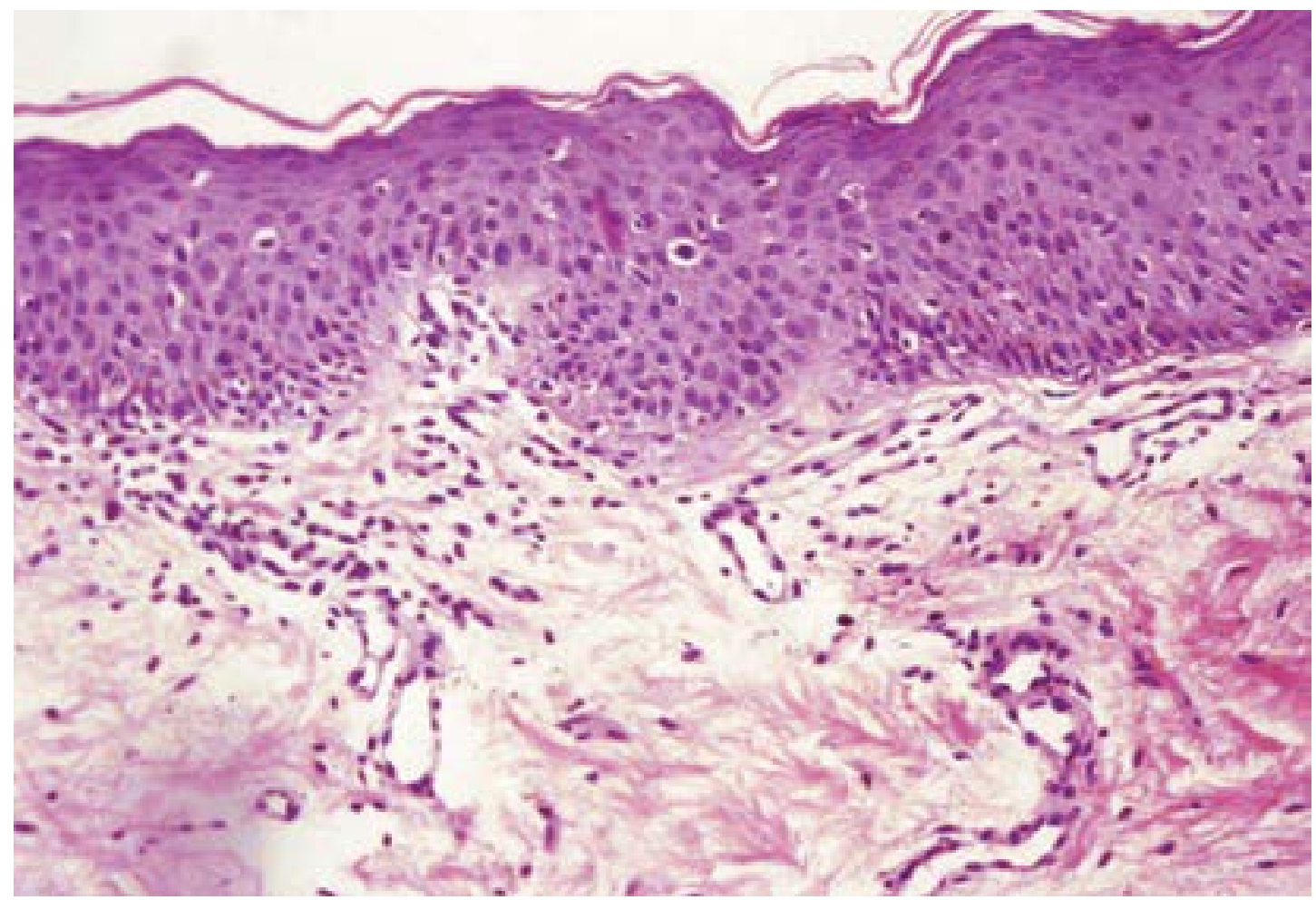

Figure 3. Microphotograph of a biopsy specimen - fragment: mild edema of lamina propria, dilated blood vessels with sparse perivascular infiltrates. Epithelium shows mild to moderate disturbed polarity and cell maturity (HE, x 200) 
and suppuration, erythema, mild itching, burning and desquamation. Inflammation, exudation and suppuration with massive desquamation were most severe during the third and fourth week of therapy. After 10 weeks of such treatment, topical fusidic acid and gentamicin creams were used in the following 4 weeks, without other drugs or topical agents. After 14 weeks, complete remission was achieved (Fig. 4a, 4b). In the following period of 18 months no recurrence was observed.

\section{Discussion}

Penile intraepithelial neoplasia or epithelial dysplasia of the penis is graded I, II, III, depending on the extent of epithelial involvement by atypical basaloid cells. These cells vary in shape and size, they have hyperchromatic pleomorphic nuclei and loss of polarity. Furthermore, grade I epithelial neoplasia (PIN I) is characterized by atypical cells involving one third of the epithelium, grade II involves two thirds, and grade III involves over two thirds of the epithelium $(1,2)$. This classification was accepted and recommended by the World Health Organization (WHO) $(1,2,4)$.
All grades of PIN are histological pre-stages of carcinoma in situ and include clinical entities previously considered to be precancerous lesions: erythroplasia Queyrat (EQ), Bowen's disease of the glans penis (BDP), bowenoid papulosis (BP), Paget disease (PD) which is an intraepithelial form of adenocarcinoma primarily found in the epithelium (4). In the absence of a formal consensus on clinicopathological classification (regarding particularly the 'grade'), in the past PIN corresponding to cervical, vulvar and anal intraepithelial neoplasia, CIN, VIN and AIN, was considered as a convenient umbrella term. In 2000, an alternative expression: "squamous intraepithelial lesion" (SIL) has been proposed and qualified by the descriptor 'high-' or 'low-grade' (5). Although EQ and BDP are synonymous in describing carcinoma in situ of the penis, BD is used to refer to squamous cell carcinoma in situ at other cutaneous sites. EQ should be used to describe shiny red patches of the 'mucosal' penis (glans and prepuce of the uncircumcised) and BDP refers to scaly patches and plaques of the keratinized penis. BP is analogous to, but clinically different from, EQ and BDP and the term should be used to describe multiple warty lesions, which are often pigmented in keratinized sites, and more numerous

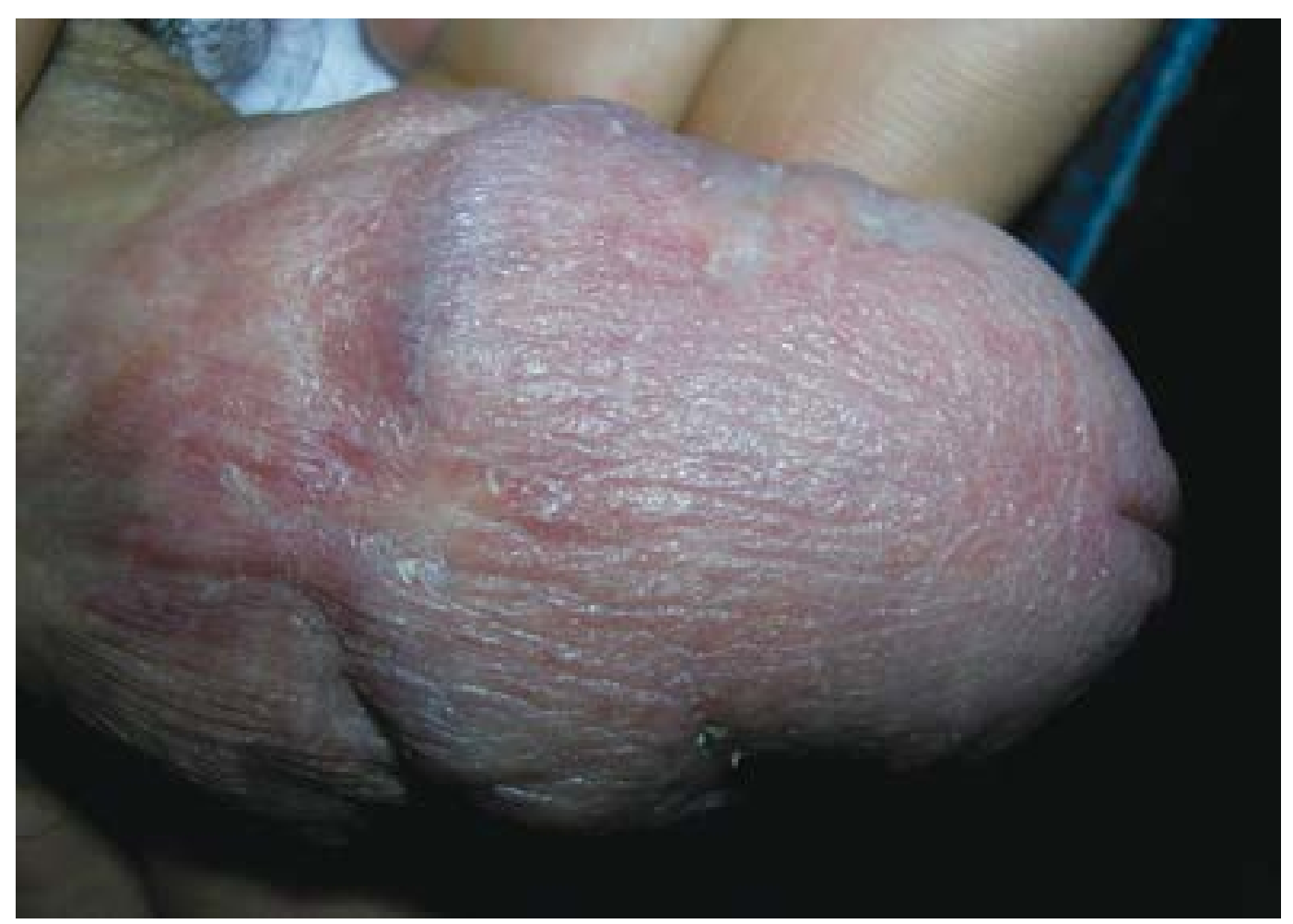

Figure 4a. Appearance 4 weeks after the 5\% imiquimod cream therapy 


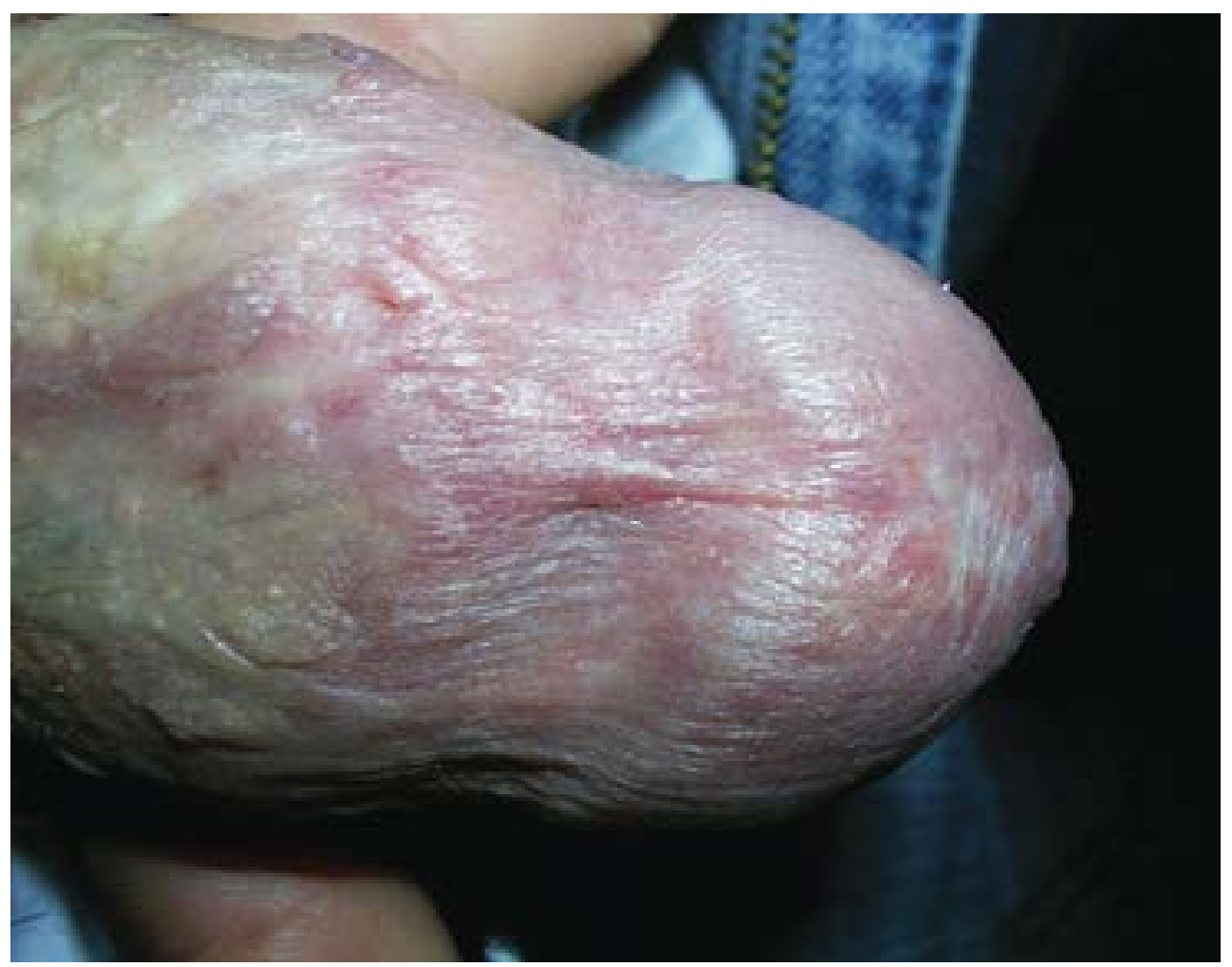

Figure 4b. Appearance 4 weeks after the 5\% imiquimod cream therapy

and more inflamed at 'mucosal' sites. In contrast to common genital viral condylomata acuminata, BP lesions occur in younger, sexually active men, clinically they are less papillomatous, smoother, more polymorphic and more coalescent (3).

Although the etiology of PIN is not completely understood, the literature indicates that human papilloma virus (HPV) plays a significant role in its etiopathogenesis $(1,2,3,4,6)$. About 30 different HPV types may be present in PIN lesions. They can be classified into low-oncogenic risk types (6 and 11), and potentially high risk types (16 and 18). Since 2007, literature data point to the importance of microscopic appearance of HPV infected cells in the spinous layer of the penile mucous epithelium, mostly in men under 40 years of age: koilocytosis, dyskeratosis and acanthosis. This histological finding may indicate III grade PIN and provide a timely treatment plan (4).

Imiquimod, 1-(2-methylpropropyl)-1 $\mathrm{H}$-imidazole [4,5-c]quinolin-4-amine, belongs to a group of drugs known as imidazoquinolines that are immune response modifiers with potent antiviral and antitumor activity. Thus, imiquimod represents an imidazoquinoline immunomodulator drug, a toll-like receptor agonist, which induces cytokine production and stimulates the innate and cellular immune responses. Imiquimod is currently used in the management of anogenital warts, actinic keratoses, basal cell carcinoma and other skin lesions, including lentigo maligna (7). The mechanism of its action is likely to be mediated by Toll-like receptor 7 (TLR-7), which represents a cell surface receptor found on monocyte cells. Stimulation of TLR7 receptor results in a release of large amounts of potent cytokines such as interferon- $\alpha$, IL-12, and TNF- $\alpha$. In addition to stimulation of the innate response, these cytokines promote the development of antigen-specific, cell-mediated immune response (8). Imiquimod 5\% cream is a topical immunomodulator, but is used as a topical agent against human papilloma viruses as well. It has been shown under in vivo conditions in experimental animals, that imiquimod inhibits cell proliferation in the epidermis of the skin via an opioid receptor mediated mechanism (9). Fortunately, there is no concern for physical dependence since, imiquimod is neither an opioid agonist nor antagonist.

The first clinical application in which imiquimod proved to be useful was for treatment of genital warts, but imiquimod would seem to have a potential in 
many additional applications, including treatment of: actinic keratosis, superficial basal cell carcinoma (BCK) less than $2,0 \mathrm{~cm}$ in diameter, genital and perianal warts, keratoacanthoma, porokeratosis, as well as in situ malignancies (10,11-14). Partial and complete responses have been observed in the treatment of cervical, vaginal and vulvar intraepithelial neoplasia and Bowenoid papulosis, although the results have not been consistent (15-17). Imiquimod is contraindicated in immunosuppressed patients and patients with autoimmune diseases. The frequency and length of imiquimod treatment depend on indications: actinic keratoses have been shown to respond after using imiquimod three times weekly for up to 12 weeks (18); Bowen's disease after daily application for up to 16 weeks (19); actinic cheilitis responded well to imiquimod applied three times weekly for up to 6 weeks (20); in superficial BCC 6 week treatment appeared as effective as the 12 week therapy $(21,22)$. Local skin reactions were common, but these are thought to reflect the immune response to the tumor. The cream should not be used for more than 16 weeks. It is broadly well tolerated; local application-site reactions, including pruritus, erythema, edema and bleeding are common, usually mild, and do not necessitate discontinuation of therapy $(2,4,6,10-13,23,24)$. Inflammatory papules in the surrounding skin have been recorded (14). There is evidence that the more severe the local reaction, the higher the clearance rate (23), without compromising the eventual cosmetic results (24).

According to current literature, topical 5\% imiquimod is a treatment option for PIN, while length of follow-up period is of utmost importance in order to detect recurrences $(7,10)$. In our patient the follow-up lasted 18 months (until present).

Literature data show other treatment options for PIN: 5-fluorouracil cream, cryotherapy, curettage and cautery, $\mathrm{CO}_{2}$-laser, photodynamic therapy, radiation therapy (which should be avoided), interferon-alpha, excision and Mohs micrographic surgery (particularly in the treatment of recurrences). Special attention should be paid to regular check-ups of sexual partners of HIV-infected patients with PIN, in order to provide early diagnosis and treatment of cervical, vulvar and anal carcinoma (25).

\section{Conclusion}

This is a case report of a patient with penile intraepithelial neoplasia successfully treated with 5\% imiquimod cream during 10 weeks, and a follow-up period of 18 months. During this period no recurrence was reported. Although topical use of 5\% imiquimod cream proved to be successful in the treatment of penile intraepithelial neoplasia grade I and II, final assessment of its therapeutic effects requires a longer period of observation in order to detect any potential recurrence of lesions.

\section{Abbreviations}

\author{
PIN - Penile intraepithelial neoplasia \\ SCC - Squamous cell csrcinoma \\ HPV - Human papilloma virus \\ HIV - Human immunodeficiency virus \\ EQ - Erythroplasia of Queyrat - erythroplasia \\ of Queyrat \\ BDP - Bowen's disease of the penis \\ BP - Bowenoid papulosis \\ CIN - Cervical intraepithelial neoplasia \\ VIN - Vulval intraepithelial neoplasia \\ AIN - Anal intraepithelial neoplasia \\ SIL - Squamous intraepithelial lesion \\ TLR-7 - Toll-like receptor 7 \\ IL-12 - Interleukin-12 \\ TNF- $\alpha$. - Tumor necrosis factor $-\alpha$ \\ BCK - Basal cell carcinoma
}

\section{References}

1. Aynaud O, Ionesco M, Barrasso R. Penile intraepithelial neoplasia: specific clinical features correlate with histologic and virologic findings. Cancer 1994;74(6):1762-7.

2. Cubilla A, Dilliner J, Schellhammer PF, Horenblas S, Ayala AG, Reuter VA, et al. Malignant epithelial tumors. In: Eble NJ, Sauter G, Epstein IJ, Sesterhenn IA. World Health organization classification of tumours: pathology and genetics of tumors of the urinary system and male genital tumors. Lyon: IARC Press; 2004. p. $281-90$

3. Bunker CB, Neill SM. The genital, perianal and umbilical regions. In: Burns T, Breathnach S, Cox N, Griffiths C, editors. Rook's textbook of dermatology. $\sigma^{\text {th }}$ ed. Oxford: Blackwell Publishing Ltd; 2010. p. 71.1-102.

4. Wikström A, Hedblad A, Syrjänen S. Penile intraepithelial neoplasia: histopathological evaluation, HPV typing, clinical presentation and treatment. J Eur Acad Dermatol Venereol 2012;26:325-30.

5. Cubilla AL, Velazques EF, Reuter VE, Oliva E, Mihm MC, Young RH. Warty (condylomatous) squamous cell carcinoma of the penis: a report of 11 cases and proposed classification of 'verruciform' penile tumors. Am J Surg Pathol 2000;24:505-12. 6. Cubilla AL, Velazquez EF, Young RH. Epithelial lesions associated with invasive penile squamous cell carcinoma: a pathologic study of 288 cases. Int J Surg Pathol 2004;12(4):351-64.

7. Wagstaff AJ, Perry CM. Topical imiquimod: a review of its use in the management of anogenital warts, actinic keratoses, basal cell 
carcinoma and other skin lesions. Drugs 2007;67(15):2187-210. 8. Berth-Jones J. Topical treatment. In: Burns T, Breathnach $S$, Cox N, Griffiths C, editors. Rook's textbook of dermatology. $6^{\text {th }}$ ed. Oxford: Blackwell Publishing Ltd; 2010. p. 73.1-52.

9. McLaughlin PJ, Rogosnitzky M, Zagon IS. Inhibition of DNA synthesis in mouse epidermis by topical imiquimod is dependent on opioid receptors. Exp Biol Med 2010;235:1292-9.

10. Gaspari A, Tyring SK, Rosen T. Beyond a decade of 5\% imiquimod topical therapy. J Drugs Dermatol 2009;8(5):467-74. 11. Rivers JK, Rosoph L, Provost N, Bissonnette R. Open-label study to assess the safety and efficacy of imiquimod 5\% cream applied once daily three times per week in cycles for treatment of actinic keratoses on the head. J Cutan Med Surg 2008;12:97-101.

12. Choi JW, Choi M, Cho KH. A case of erythroplasia of queyrat treated with imiquimod 5\% cream and excision. Ann Dermatol 2009;21(4):419-22.

13. Wigbels B, Luger T, Metze D. Imiquimod: a new treatment possibility in bowenoid papulosis? Hautarzt 2001;52(2):128-31. 14. Bhatia N. Imiquimod as a possible treatment for keratoacanthoma. J Drugs Dermatol 2004;3(1):71-4.

15. Diaz-Arrastia C, Arany I, Robazetti SC, Dinh TV, Gatalica Z, Hannigan E. Clinical and molecular responses in high grade intraepithelial neoplasia treated with topical imiquimod 5\%. Clin Cancer Res 2001;7:3031-3.

16. Todd RW, Etherington IJ, Luesley DM. The effects of 5\% imiquimod cream on highgrade vulval intraepithelial neoplasia. Gynecol Oncol 2002;85:67-70.

17. Porter WM, Francis N, Hawkins D, Dinneen M, Bunker

CB. Penile intraepithelial neoplasia: clinical spectrum and treatment of 35 cases. Br J Dermatol 2002;147:1159-65. 18. Stockfleth E, Meyer T, Benninghoff B, Salasche S, Papadopoulos L, Ulrich C, et al. A randomized, double-blind, vehicle controlled study to assess $5 \%$ imiquimod cream for the treatment of multiple actinic keratoses. Arch Dermatol 2002;138:1498-502.

19. MacKenzie-Wood A, Kossard S, de Launey J. Imiquimod $5 \%$ cream in the treatment of Bowen's disease. J Am Acad Dermatol 2001;44:462-70.

20. Smith KJ, Germain M, Yeager J, Skelton H. Topical 5\% imiquimod for the therapy of actinic cheilitis. J Am Acad Dermatol 2002;47:497-501.

21. Marks R, Gebauer K, Shumack S, Amies M, Bryden J, Fox $\mathrm{TL}$, et al. Imiquimod $5 \%$ cream in the treatment of superficial basal cell carcinoma: results of a multicentre 6 week doseresponse trial. J Am Acad Dermatol 2001;44:807-13.

22 Geisse J, Rich P, Pandya A, Gross K, Andres K, Ginkel A, et al. Imiquimod $5 \%$ cream for the treatment of superficial basal cell carcinoma: a double-blind randomized vehicle-controlled study. J Am Acad Dermatol 2002;47:390-8.

23. Jaleel H, Narouz N, Wade AA, Allan PS. Penile intraepithelial neoplasia: a veiled lesion in genitourinary medicine. Sex Transm Infect 1999;75:435-6.

24. Perras C. Imiquimod 5\% cream for actinic keratosis. Issues Emerg Health Technol 2004;(61):1-4.

25. Kreuter A, Brockmeyer NH, Weissenborn SJ, Gambichler T, Stücker M, Altmeyer P, et al. Penile intraepithelial neoplasia is frequent in HIV-positive men with anal dysplasia. J Invest Dermatol 2008;128:2316-24.

\section{Epitelna displazija penisa - lokalno lečenje imikvimodom u obliku $5 \%$ krema - prikaz slučaja}

\section{Sažetak}

Uvod: Pojam epitelne displazije označava prisustvo epitelnih ćelija poremećene polarnosti i sazrevanja, sa atipijom nukleusa, povećanom mitotskom aktivnošću i poremećenim jedarno-citoplazmatskim odnosom. Danas se za navedene promene $\mathrm{u}$ predelu glansa i prepucijuma penisa ravnopravno upotrebljavaju pojmovi epitelne displazije penisa i intraepitelne neoplazije penisa (PIN - engl. penile intraepithelial neoplasia). PIN obuhvata kliničke entitete ranije smatrane prekancerozama. Svi stepeni epitelne displazije odnosno PIN, predstavljaju histološke predstadijume carcinoma in situ i vremenom mogu da dovode do pojave karcinoma skvamoznih (spinoznih) ćelija - SCC (eng. squamous cell carcinoma) penisa. PIN odnosno epitelna displazija penisa I, II i III stepena graduisana je prema stepenu debljine zahvatanja epitela atipičnim bazaloidnim ćelijama. U literaturi se navodi značajna uloga humanih papiloma virusa (HPV) u etiopatogenezi PIN.

Prikaz slučaja: Autori prikazuju muškarca starog 36 godina $s$ epitelnom displazijom na glansu penisa, koji je u decembru 2010. godine pregledan u dermatovenerološkoj službi specijalističke Poliklinike Kliničkog centra Vojvodine. Pacijenta je na pregled uputio regionalni urolog sa histopatološkom analizom biopsije koja je uzeta sa 4 različita mesta sa plakoznih promena na glansu penisa. U 15. godini života je operisan od fimoze (cirkumcizija). Nije imao malignih bolesti niti drugih sistemskih bolesti.

U momentu pregleda, klinički nalaz na glansu je odgovarao neznatno induriranim eritematoznim plakovima sa lakom deskvamacijom na površini, cirkumferentnog rasporeda sa tendencijom difuznog zahvatanja celog glansa penisa.

Histopatološki nalaz: sa sva 4 mesta bioptirane sluznice glansa histopatološki nalaz odgovara sluznici 
sa pločasto slojevitim epitelom u kome se uočava: blaga parakeratoza, blago do srednje narušena slojevitost ćelija; poremećeno sazrevanje pojedinih ćelija; uvećanje pojedinih jedara koja su krupnija i sa vidljivim jedarcima; prisustvo perinuklearnog svetlog haloa (diskretna koilocitoza) na pojedinim ćelijama; bazalna membrana očuvane i podjednake debljine; neravnomerno raspoređeni infiltrat limfocita i plazma ćelija u blago edematoznoj lamini propriji, oko blago dilatiranih krvnih sudova; odsustvo diskeratoze. $\mathrm{Na}$ osnovu navedene analize zaključeno je da se radi o: dysplasio epithelii planocellularis gradus levioris (I) et partim gradus mediocris (II) mucosae.

Lečenje: Imiquimod 5\% krem nanošen je jedanput dnevno u tankom sloju i ostajao je 8 sati (potom pranje vodom i sapunom do novog nanošenja) svaki dan tokom 5 dana u nedelji, potom 2 dana pauze, u toku ukupno 10 nedelja. $\mathrm{Na}$ svake 2 nedelje tokom ovog tretmana činjeni su kontrolni pregledi kod dermatologa. $\mathrm{Na}$ kontrolnim pregledima utvrđeno je postojanje lokalne inflamacije sa lakom eksudacijom i supuracijom, eritem, blag svrab, pečenje i deskvamacija. Najjača inflamacija, eksudacija i supuracija sa izraženom deskvamacijom bila je tokom treće i četvrte nedelje lečenja. Posle 10 nedelja lokalnog tretmana ovim kremom, uvedena je lokalna primena masti sa fusidinskom kiselinom i gentamicinom u toku naredne 4 nedelje lokalnog tretmana, bez drugih peroralnih i lokalnih lekova. Nakon 14 nedelja od započinjanja lečenja, došlo je do kompletne sanacije promena. Tokom sledećih 18 meseci praćenja, nije bilo recidiva.

Diskusija: PIN odnosno epitelna displazija penisa I, II i III stepena graduisana je prema stepenu zahvatanja debljine epitela atipičnim bazaloidnim ćelijama. Ove ćelije variraju po svom obliku i veličini, imaju hiperhromatska pleomorfna jedra, sa gubitkom polarnosti. Pri tome, epitelnu neoplaziju stepena I (PIN I) karakteriše zahvatanje atipičnim ćelijama do jedne trećine debljine epitela, stepen II ide do dve trećine debljine epitela, a stepen III karakteriše zahvatanje atipičnim ćelijama više od dve trećine debljine epitela. Navedenu klasifikaciju prihvatila je i preporučuje je Svetska zdravstvena organizacija (engl. WHO - World health organization). Svi stepeni epitelne displazije odnosno PIN, predstavljaju histološke predstadijume carcinoma in situ i obuhvataju kliničke entitete ranije smatrane prekancerozama: erythroplasia Queyrat (engl. erythroplasia of Queyrat - EQ), Bowenova bolest penisa (engl. Bowen's disease of the penis - BDP), bovenoidna papuloza (engl. bowenoid papulosis - BP); Pagetova bolest, koja predstavlja intraepitelnu formu adenokarcinoma primarno nastalog u epitelu.

Iako je etiologija PIN nedovoljno razjašnjena, u literaturi se navodi značajna etiopatogenetska uloga humanih papiloma virusa (HPV). Oko 30 različitih tipova HPV virusa može biti prisutno u lezijama PIN sa podelom na one sa niskim onkogenim potencijalom (tipovi 6 i 11) i visokim onkogenim rizikom (tipovi 16 i 18). U svetskoj literaturi se od 2007 . godine ukazuje na značaj mikroskopskog izgleda ćelija inficiranih virusom u spinoznom sloju epitela mukoze penisa, posebno kod muškaraca mlađih od 40 godina: koilocitoza, diskeratoza i akantoliza. Ovaj histološki nalaz može indikovati prisustvo PIN I-III stepena i omogućiti blagovremeni terapijski pristup.

U savremenoj literaturi se 5\% imivimod krem navodi kao jedan od metoda lečenja PIN i ističe da je bitna dužina perioda praćenja bolesnika radi rane detekcije pojave recidiva. U našem slučaju period praćenja je za sada 18 meseci.

U literaturi se navode i druge metode lečenja PIN: 5-fluorouracil krem, krioterapija, kiretaža i kauterizacija, $\mathrm{CO}_{2}$-laser, fotodinamička terapija, radioterapija (koju treba izbegavati), interferon alfa, ekscizija i Mohsova mikrografska hirurgija (naročito u lečenju recidiva). Posebnu pažnju u smislu redovnih kontrolnih pregleda treba pružiti seksualnim partnerima osoba HIVinficiranih sa PIN, sa ciljem ranog otkrivanja i lečenja cervikalnog, vulvarnog i analnog karcinoma [25].

Zaključak: U radu je prikazan slučaj intraepitelne neoplazije penisa koji je uspešno lečen sa 5\% imikvimod kremom tokom 10 nedelja, sa periodom praćenja od 18 meseci. U tom periodu nije bilo recidiva. Iako se metoda lokalne primene 5\% imikvimod krema pokazala uspešnom u lečenju intraepitelne neoplazije penisa prvenstveno stepena I i II, za procenu krajnjeg terapijskog efekta potreban je duži period praćenja radi otkrivanja eventualne pojave recidivantnih promena.

\section{Ključne reči}

Neoplazme penisa; Aminokvinolini; Topikalna primena; Ishod lečenja 